\title{
Profitability Indicators of Business at the Policy of Fiscal Stimulus
}

\author{
Sumiati $^{1}$, Erina Sudaryati ${ }^{2}$ \\ Bussiness and Economic Faculty of Airlangga University, Indonesia
}

\begin{abstract}
Tax incentives are part of the Policy of Fiscal Stimulus. The policy of fiscal stimulus is expected to improve the business profitability of the companies. Besides providing profit margin ratio, Ratio of operating profit, Ratio Net Profit, return on asset (ROA), and return on profit Equity (ROE). This researchused sample 60 companies try to investigate further about the measure of in Business Profitability Indicators atFiscal Stimulus Policy in 2015-2016. The data which is used in this research is secondary data. That is, the data which was obtained from the financial data of the Indonesia Stock Exchange (BEI) by using purposive sampling method which was published financial report between 2015-2016. The analysis method of this research used multi regression and single regression. There is a significant difference in the Gross Profit Margin Ratio while Profitability Ratio of Operating Income, Net Profit Margin Ratio, Return on Assets (ROA), and Return On Equity (ROE) do not have significant Fiscal Stimulus Policy effect due to operating activities, assets and capital yet used effectively.
\end{abstract}

Keyword : Business Profitability, Fiscal Stimulus Policy, Tax, ROA, ROE

\section{Introduction}

In the economy of a country, the role of the business world and the world of industry strongly support the State budget. The weakening of the business world and the world of industry leads against the fall in the tax sector of acceptance [1]. In order for the business to survive, the crisis and in accordance with the purchasing power of income tax rates, then good for an individual or company by the Government need to be lowered. Meanwhile, the tax component of the reconstruction to be sworn production costs, so that the company can continue to survive by maintaining the selling price. The government's attempt to reduce the tax burden is referred to as fiscal incentives.

Fiscal incentive is one of the Government's policies in regard to the granting of tax incentives (tax incentives). Tax incentives according to [6], is a grant of the tax facilities given to overseas investors for certain activities or for a particular area [2]. One of the other things that the Government is to publish a presidential instruction No.3 of the year 2006 about the investment climate Improvement Policy Package. In a package of improvements to the investment climate is one of the important policy is to provide tax incentives for foreign and local investment.

The application of the fiscal stimulus is that of the Indonesian economy [3]. The funds needed for the fiscal stimulus provided in the budget of the State Expenditures and Revenues (NATIONAL BUDGET) 2015 is a little burdensome State spending, because it reduces State revenue over tax. Total fiscal stimulus funds provided in the BUDGET of 2015 Rp. 71.3 billion (1.4\% of GDP). Fiscal stimulus amounting to it among other savings will be used for the payment of taxes (tax saving). By using the remainder of the 2008 STATE BUDGET and spends the use of STATE BUDGET for the 2015 fiscal stimulus, Governments expect to be able to stimulate the economy again moving forward.

Problems that happen with respect to the author's research is the decline in the profit structure of the company in operating profit, that is declined in the period of fiscal stimulus policy years 2009 and 2010, this is because the above activity has not been carried out effectively in generating profit for the company. Government 
policy in granting tax incentives in this case is the development of industrial sector [4]. So besides the granting of fiscal stimulus, increasing the profitability of the businesses must also be improved. The profitability of the venture is the ability of a company to generate profit during a certain period [5]. By measuring the profitability of the company, achieving the achievements of the undertaken activities. To be able to realize the industrial sector, besides granting fiscal stimulus efforts increased the profitability of businesses in any industry sector should be improved.

\section{Literature Review and Reseach Method}

\subsection{Literature Review}

Profitability is the ability of a company to generate profit during a certain period [7]. While according to Ridwan and Inge [8] is the Profitability ratio to measure the effectiveness of the overall management addressed by the great small level of profit earning in relation to sales and investment. While according to Dewi Astuti [9] Profitability that is measuring the company's ability to generate earnings. Understanding the profitability of the above, it can be inferred that profitability is the ability of a company in obtaining or producing profitsin relation to sales and investment in a certain period.

Ratio to measure profitability there are several types, each of which is linked against sales, assets, capital or stock value [10]. Ratio which is often a concern and a major focus of investors or shareholders is net profit. Shareholders and potential investors are very interested to know the calculation of the net profit of the company. Because before deciding to make an investment they have to evaluate their earnings. To analyze the profitability of the company, then use a profitability ratio.

Ratio of capability of generating profit (Ratio of Profitability) there are 5 (five) size ratio used to measure the ability of generating profits, i.e. the Ratio of Operating Profit Margin Ratio, the Ratio Net Profit (Net Profit Margin Ratio), the Ratio Net Profit Against Assets (Return on Assets, the Ratio of Net profit to capital (Return On Equity) [11] Tax constitutes acceptance of the most important countries and most important taxes are for the most important thing in enhancing national development [12] Below is the definition of the tax as "Taxes are the dues to the State (which may be imposed) owed by mandatory pay it according to the rules, with no accomplishment gets back, that may be appointed, and that point is to finance public spending-spending in relation to the duty of the State which hosts the Government "[13].

Based on the official website of the Directorate-General of Budget (www.budget-info.com, downloaded on 23 December 2011) Fiscal Stimulus (fiscal stimulus) is part of the Government's fiscal policy aimed at influencing aggregate demand (aggregate demand) that (expected) to be more general terminology, given the Fiscal Stimulus when the economy is at the lowest level where growth rates are likely to experience declining continuously [14]. There are two forms of fiscal instruments are used, namely Withholding tax (a tax cut) and raise the magnitude of government spending Theoretically, the Fiscal Stimulus works in the short term. That is, the Fiscal Stimulus faster affect aggregate demand components so that it will also encourage more rapid rate of growth of the output of business sectors. Inappropriate with the concept of anyway, Fiscal Stimulus policies designed by the bull's-eye and also move faster growth in the real sector. Inappropriate with the concept, the Fiscal Stimulus in the bull's-eye, in addition to shorter adjustment time, will also hold the (temporary) drop in the economic growth figures.

\subsection{Research method}

The study used a sample of 60 manufacturing companies that are trying to investigate further on the size of Business Profitability Indicators on the Fiscal Stimulus Policy in 2015-2016. The data used in this research is secondary data. The data is obtained from the financial data of Indonesia Stock Exchange (IDX) by using purposive sampling method that publishes financial statements between 2015-2016. The method of analysis used in this study is regression multi regression and single regression.

Profitability analysis using the ratio of gross profit (Gross Profit Margin Ratio), the Ratio of operating profit (Operating Profit Margin Ratio), the Ratio Net Profit (Net Profit Margin Ratio), the Ratio Net Profit Against Assets (Return on Assets = ROA ), the Ratio net profit To Capital (Return On Equity). 


\section{Result}

The ratio of gross profit (Gross Profit Margin Ratio), the Ratio of operating profit ( Operating Profit Margin Ratio), the Ratio Net Profit (Net Profit Margin Ratio), the Ratio Net Profit Against Assets (Return on Assets), the Ratio Net Profit To Capital (Return On Equity).Furthermore when seen from the minimum, maximum, average (mean) and standard deviation $(\delta)$ of each variable of the research can be seen in table I:

TABLE I. Calculation of the Minimum, maximum, Mean and standard deviation Descriptive Statistics

\begin{tabular}{|l|l|l|l|l|l|l|}
\hline \multirow{2}{*}{} & $\mathrm{N}$ & Minimum & Maximum & Mean & Std. Deviation \\
\cline { 2 - 7 } & Statistic & Statistic & Statistic & Statistic & Std. Error & Statistic \\
\hline ratio of gross profit & 60 &, 0082 &, 3673 &, 184650 &, 0123683 &, 0958041 \\
Ratio of operating profit & 60 &, 0141 &, 4502 &, 172415 &, 0135099 &, 1046470 \\
Ratio Net Profit & 60 &, 0141 &, 4502 &, 137293 &, 0125236 &, 0970072 \\
ROA & 60 &, 0082 &, 3304 &, 143023 &, 0120586 &, 0934052 \\
ROE & 60 &, 0082 &, 3304 &, 148013 &, 0117747 &, 0912068 \\
Valid N (listwise) & 60 & & & & & \\
\hline
\end{tabular}

The average value of above and the value of the standard deviation of his average shows good results, that is because the standard deviation of deviations of data that reflects the variable is smaller than average. To determine the data with Kolmogorov-Smirnov test, the value of significance must be above 0.05 or $5 \%$ [15].For more details can be seen in Table II.

TABLE II. One-Sample Kolmogorov-Smirnov Test

\begin{tabular}{|c|c|c|c|c|c|c|}
\hline & & $\begin{array}{c}\text { ratio of } \\
\text { gross profit }\end{array}$ & $\begin{array}{c}\text { Ratio of } \\
\text { operating } \\
\text { profit }\end{array}$ & $\begin{array}{c}\text { Ratio Net } \\
\text { Profit }\end{array}$ & ROA & ROE \\
\hline \multirow[t]{2}{*}{$\mathrm{N}$} & & 60 & 60 & 60 & 60 & 60 \\
\hline & Mean &, 184650 &, 172415 & , 137293 &, 143023 & , 148013 \\
\hline \multirow[t]{2}{*}{ Normal Parameters ${ }^{\mathrm{a}, \mathrm{b}}$} & Std. & ,0958041 &, 1046470 & ,0970072 & ,0934052 & ,0912068 \\
\hline & Absolute & 089 & 097 & 102 &, 116 & 120 \\
\hline \multirow[t]{2}{*}{ Most Extreme Differences } & Positive & 067 & ,097 & 092 &, 116 &, 120 \\
\hline & Negative &,- 089 &,- 074 &,- 102 &,- 076 &,- 094 \\
\hline Kolmogorov-Smirnov Z & & 692 &, 754 & ,790 & ,895 & ,929 \\
\hline Asymp. Sig. (2-tailed) & &, 724 & 620 &, 560 & ,400 & ,354 \\
\hline
\end{tabular}

a. Test distribution is Normal.

b. Calculated from data.

Based on the results in table 4.2 of that it appears that all the variables showed a normal distributed data $(0.724,0.620,0.560,0.400$ and 0.354$)$ in which the value of the kolmogorov smirnov significance greater than 0.05 .

\subsection{Conclussion}

BUDGET years 2016 through increased productivity of the STATE BUDGET, the creation of a conducive investment climate as well as the strengthening fiscal buffers, as well as the country's financial management that is flexible and wise. The formulation of fiscal policies should also consider the harmonization efforts and balance between the fulfillment of public service, the acceleration of the achievement of national development targets, and increased social protection to improve the financial profitability of the company. The implementation of Fiscal Stimulus Policies in companies judged to be good enough even though Profitability, companies should be able to streamline the activities of the operation and use of the asset and capital of companies efficiently and efficiently in order to improve the profits the company.

\section{Acknowledgements}

Gratitude and greatest gratitude I love to God Almighty, and both parents and my family who have always supported the work of this research. I also thank Dr. Erina Sudaryati as my research supervisor. I thank you also for all friends who support to complete this research. 


\section{References}

[1] Nye Jr, J. S. (2016). Bound to lead: The changing nature of American power. Basic Books.

[2] Warsono, W., \& Ardianto, Y. (2017). Pengaruh Corporate Social Responsibility Terhadap Agresivitas Pajak dengan Insentif Pajak Sebagai Pemoderasi.(Studi pada perusahaan pertambangan di Indonesia). Jurnal Manajemen dan Bisnis Indonesia, 2(2), 236-249.

[3] Karanikolos, M., Mladovsky, P., Cylus, J., Thomson, S., Basu, S., Stuckler, D., ...\& McKee, M. (2013). Financial crisis, austerity, and health in Europe. The Lancet, 381(9874), 1323-1331.

[4] Blanchard, O. J., Cottarelli, C., Spilimbergo, A., \& Symansky, S. (2009). Fiscal policy for the crisis.

[5] Seelos, C., \& Mair, J. (2007). Profitable business models and market creation in the context of deep poverty: A strategic view. The academy of management perspectives, 21(4), 49-63.

[6] Suandy,Erly 2011, Perencanaan Pajak, Salemba Empat, Jakarta.

[7] Riyanto, Bambang. 2007. Dasar-dasar Pembelanjaan perusahaan. Yogyakarta: BPFE

[8] Ridwan S. Sundjaja dan inge Barlian, 2007, Manajemen Keuangan Dua, Edisi Keempat, Literata Lintas Media, Jakarta.

[9] Astuti, Dewi, 2004. Manajemen Keuangan Perusahaan, Jakarta: Ghalia Indonesia.

[10] Pew Tan, H., Plowman, D., \& Hancock, P. (2007). Intellectual capital and financial returns of companies. Journal of Intellectual capital, 8(1), 76-95.

[11] Dermawan Sjahrial. 2007. Manajemen Keuangan. Mitra Wacana Media : Jakarta.

[12] Jalan, A., Jalan, A., Vaidyanathan, R., \& Vaidyanathan, R. (2017). Tax havens: Conduits for corporate tax malfeasance. Journal of Financial Regulation and Compliance, 25(1), 86-104.

[13] Waluyo, 2007, Perpajakn Indonesia, edisi 2, Jakarta: Salemba empat.

[14] Ghosh, A. R., Kim, J. I., Mendoza, E. G., Ostry, J. D., \& Qureshi, M. S. (2013). Fiscal fatigue, fiscal space and debt sustainability in advanced economies. The Economic Journal, 123(566).

[15] Ghozali, Imam. (2002). Aplikasi Analisis Multivariate Dengan Program SPSS. Semarang: UNDIP 